The Methodological Aspect of Using Associated Exercises for Working with Wimmelbuch at

English Lessons in Primary School

UDC 372.881.111.1

\title{
THE METHODOLOGICAL ASPECT OF USING ASSOCIATED EXERCISES FOR WORKING WITH WIMMELBUCH AT ENGLISH LESSONS IN PRIMARY SCHOOL
}

\author{
Iryna Lobachova \\ Candidate of Philological Sciences, Associate Professor of \\ Primary Education Theory and Practice Department \\ SHEE "Donbas State Pedagogical University" \\ Sloviansk, Donetsk Region, Ukraine \\ http://orcid.org/0000-0001-7102-1915 \\ sbitneva.irina@ukr.net
}

\begin{abstract}
The article describes the methodological aspect of using associative exercises for working with illustrative material of Wimmelbuch at English lessons in primary school. It is found out that much attention is given to teaching a foreign language to schoolchildren at the age between six and seven whose age characteristics determine moving and motor activity and a significant role of the nonverbal component in self-expression. It is determined that non-verbal actions play an important part in communication and have a significant influence on the partner, so this fact should be taken into account while teaching foreign language communication.

The purpose of the study is to find out the didactic conditions for using associative exercises to work with the Wimmelbuch at English lessons in primary school.

The relevance of the outlined problem is determined by the lack of development of the intercultural and activity approaches to the issue of using associative exercises to work with the Wimmelbuch for conducting intercultural communication.

The article proves that the illustrative materials of the Wimmelbuch helps to realize the principles of the concept of personality's development in cross-cultural activity, that meets the requirements of modern society to the level and quality of foreign language education. By using associative exercises while working with the Wimmelbuch at English lessons, the conditions are created for developing primary schoolchildren's language abilities and for training them for real communication within intercultural contacts, in which it is necessary to understand and use not only verbal but also non-verbal means of communication.

The associative exercise is specially organized training which is performed by using a large number of different analyzers (visual, auditory, speech-motor and moving). Such exercises give an opportunity to solve the main problems of teaching a foreign language to primary schoolchildren, because it is based on the actual theory of language learning through the personal activity of a child. The use of non-verbal associative symbols at foreign language lessons allows a student to perceive language material through all analyzers, and the student's need for moving activity is fully ensured.

Methodical tasks of the associative exercises are defined as to extend language abilities of students within the communicative minimum; to make studying a foreign language interesting, that will develop a student's positive attitude to learning; to bring studying a foreign language closer to free communication; to involve the language experience of students' communication in their native language to transfer it to communication in a foreign language and vice versa; to train moral qualities and culture of communication; to acquaint students with the peculiarities of socioculture of a foreign country, etc.
\end{abstract}

Key words: associative exercises; Wimmelbuch; intercultural communication; non-verbal component; primary school pupil.

Професіоналізм педагога: теоретичні й методичні аспекти. - Вип. 7. - Слов’янськ, 2018. 
Problem setting in general. According to the new Law of Ukraine "On Education" (2017), the results of learning are skills, abilities, knowledge, ways of thinking, views, values, other personal qualities acquired in the process of learning, education and development that can be identified, planned, evaluated and measured and which person is able to demonstrate after the completion of an educational program or other educational components. To achieve this goal, it is not enough to gain knowledge. Therefore, the concept of competences is to be formed in the educational process: to master the state language fluently; the ability to communicate in native and foreign languages; cultural competence and other competences provided by the standard of education [3].

Thus, changes in the approach to teaching a foreign language are observed, in particular intercultural and activity approaches are stressed. Much attention is given to teaching a foreign language to primary six- or seven-year-old schoolchildren, whose age characteristics determine moving and motor activities and a significant role of the non-verbal component in self-expression. Non-verbal actions play an important part in communication and have a great impact on the interlocutor. This should be taken into account while teaching foreign language communication, because there can not be a full-value contact with interlocutors without all the factors of which it is composed.

The latest papers and publication on the problem. Research of the non-verbal component in communication is studied by R. Baur, I. Horelov, T. Nikolaieva, A. Piz, D. Fast and others. The problem of intercultural communication is investigated by E. Vereshchahin, N. Liubimova, O. Mykhailova, L. Samovar and others. Development of different systems of exercises for teaching to speak a foreign language is engaged by I. Bim, H. Noyner, V. Tsarkova and others. The issue of the specific of communicative phenomena is studied by such scholars as M. Bovtenko, O. Bihych, L. Byrkun, V. Demiankov, Yu. Karaulov and others. The urgency of the outlined problem is determined by the lack of development within the intercultural and activity approaches to the issue of using associative exercises for working with the Wimmelbuch for performing intercultural communication.

The aim of the study is to find out the didactic conditions for using associative exercises to work with the Wimmelbuch at English lessons in primary school.

Theoretical basis of research. The concept of "intercultural communication" in scientific literature refers to the communication of people representing different cultures; adequate understanding of two participants in a communicative act belonging to different national cultures; the kind of communication, the success or failure of which is largely determined by cultural differences between communicants. In consciousness of a person in the context of the cultures' contact two or more cultures interact, the basic components of which are the languages of these cultures. Thus, the cross-cultural approach in teaching a foreign language becomes priority. The basis of this approach is comparison of the social, cultural and linguistic achievements of the native country and the foreign one. 
In this context it is expedient to observe the conception of person development in cross-cultural interaction, that meets the requirements which modern society puts to the level and quality of foreign language education. The illustrative material of the Wimmelbuch [5] helps to realize the principles of this conception. The conditions for development of children's abilities and for training students to real intercultural communication within cross-cultural contacts, in which interlocutors have to understand and use both verbal and non-verbal means of communication are created at English lessons.

Scientists have proved that teaching non-verbal means of communication with verbal ones at foreign language lessons in primary school is directly dependent on a common didactic approach; on the selection of non-verbal material that is adequate to the content and procedural characteristics of the model of didactic conditions and means; on organizing a comprehensive training non-verbal means of communication with verbal ones at foreign language lessons. The content of the teaching model should include value, personal and activity characteristics. The main factor of integrated training non-verbal means of communication to primary schoolchildren at foreign language lessons is the associative exercises.

Appeal to the scientific literature has proved that non-verbal means and verbal ones are means of expressing and understanding thoughts that determine the adequate perception and transfer of information, revealing a personality of speaker and listener. As for teaching purposes non-verbal communication is social and physiological use of non-verbal means of communication, which reflect the general cultural experience and individual personality characteristics and are used for transferring and perceiving information. This definition reflects the following aspects: systemic (non-verbal means, non-verbal language), activity (non-verbal communication as an information process), cultural experience, individual personality characteristics, the role of nonverbal means in transferring and perceiving both interlocutors' ideas [2].

Research methodology. All known methods of teaching foreign languages are aimed at mastering students' verbal skills of foreign language communication, but the non-verbal aspect either takes a small, optional place, or is not taken into account at all. However, comprehensive training in using the non-verbal means with verbal ones in communication helps to improve efficiency of mastering a foreign language by students.

Didactic conditions of teaching non-verbal communication depend on its psychological, psycholinguistic and linguistic characteristics and the specifics of teaching a foreign language at the initial stage. It is mentioned that the didactic conditions have to be ranked (the first group includes the common didactic conditions for studying in comprehensive school; the second group contains the didactic conditions for primary education; and the third involves the didactic conditions of teaching a foreign language) [1].

The main didactic conditions of the effective teaching non-verbal means of communication at foreign language lessons are clarity and substantiation of the didactic 
approach, emphasizing those statements of the concept that are the most significant for the integrated teaching of non-verbal means of communication with verbal ones; the selection of a non-verbal material according to the basic statements of the didactic approach.

The basis for teaching non-verbal means of communication at foreign language lessons can be any didactic approach. At the same time, it is important that teaching is based on the aims and principles of this approach, but not arbitrarily. Then the associative exercises for teaching non-verbal communication become a part of a system of exercises that implements the aims of this approach.

It is noted that the conception of person development in cross-cultural interaction is the theoretical model of educational priorities. This approach has its own hierarchy of aims, principles, means of learning and control, which correspond with the idea of the integrated teaching non-verbal means of communication with verbal ones for selfrealization of the primary schoolchildren personality. This approach belongs to the group of intercultural approaches recognized as the most modern and relevant in the methodology of teaching foreign languages; and is provided for teaching a foreign language starting at primary school.

Involving the non-verbal component into communicative activity creates conditions for the implementation of all the principles of the conception of person development in cross-cultural interaction. The principles of individualization and interaction are realized through non-verbal communication, when individual characteristics of personality are manifested. Using non-verbal means facilitates mutual understanding and interaction. Principles of support on students' modern needs and taking into account their future needs are realized through gaming activity of primary schoolchildren, in which the non-verbal means (associative aspect) play a huge role. The principle of emotional comfort and mental activity is completely realized through the non-verbal means, as they are a way of external expression of emotions and thoughts and serve for emotional filling of verbal utterances. The non-verbal means play an important role in implementation of the principles of communication and intercultural orientation, because they perform the same functions as verbal ones, and also have a cultural specifics. This fact is important for intercultural contacts. These principles are closely interconnected, reveal the regularities of the educational process and allow to perform educational activity in the unity of all its components in an effective way.

The non-verbal associative symbols are the language of movements, gestures, mimicry, the language of our body, the code language of representations and associations. Using such symbols improves the perception and reproduction of information, that is based on the child's ability to imagine and fantasize. According to vivid child's imagination, forms of any lexical or grammatical units are created. Primary schoolchildren memorize foreign words very quickly if it is related to a concrete image or action. 
The main purpose of teaching a foreign language to primary schoolchildren through the non-verbal associative symbols is forming elementary foreign language communicative competence and the qualities which are necessary for mastering the minimized amount of knowledge and skills. This allows young learners to acquire the skills that are necessary to start the conversation with an interlocutor, to be engaged into a dialogue, to receive and render an elementary information related to the content of communication. And also certain tasks with using non-verbal associative symbols help to full and harmoniously development of students, the realization of their personal experience, and mastering the basics of foreign language communication.

The associative exercise is specially organized training which is performed using the largest number of different analyzers (visual, auditory, speech-motor and moving). These exercises have integrated features which are observed while using non-verbal associative symbols in combination with verbal means in communicative activity [4].

Such associative exercises provide an opportunity to solve the main problems of teaching a foreign language to primary schoolchildren, because it is based on the actual theory of language learning through the child's personal activity. Using non-verbal associative symbols at foreign language lessons allows primary schoolchildren to perceive language material through all analyzers, and children's need for moving activity is fully provided.

Research results. Methodological tasks of the associative exercises are defined as to extend language abilities of students within the communicative minimum; to make learning a foreign language interesting, that will form a positive attitude of a student to learning; to make learning a foreign language closer to free communication; to involve the language experience of communication in students' native language in order to transfer it to communication in a foreign language and vice versa; to train moral qualities and culture of communication; to acquaint students with the peculiarities of the socioculture of the foreign country, etc.

It is needed to characterize the practical aspect of implementing associative exercises. Before learning a new foreign language lexical material, a teacher and students discuss how they will represent different objects, states or actions by the body language and first commenting them in native language (a mother tongue is used only to explain associative symbols). You have only one time to show to students how to represent objects or actions by the body language (e.g.: animal, lake, forest, park, zoo; how to do some things: to read a book, to play ball, to watch TV, to play a computer), and they will become the active participants of the game at the lesson.

Presentation of any educational material has the constant algorithms: 1) to agree on the way of representing a non-verbal associative symbol;2) to check understanding of this symbol; 3) to name the symbol in English and show it.

For example, the associative exercises are implemented for the study the topic "At the Zoo" using the illustrative material of the Wimmelbuch. We imitate the monkey making a funny face and putting our hands on the hips, or raise them, saying: Uh-uh-ah-uh-uh-ah!; the pony - lowering hands down and make fists showing the 
imaginary hoofs, saying: Neigh! Neigh!; the tiger - putting middle fingers on the upper lip showing the imaginary mustache and saying Raaar!; the deer - put to the head with straightened fingers showing long horns; the seal - we pull our hands to the side and clap imitating the tail, and so on. You can also simply imitate animal sounds. Each student has to choose an animal and then makes the noise, so that the others can hear how it sounds and repeat it: Baa! Meow! Moo! Woof! Quack! To whit to whoooo! Tweet! Oink! Squeak! Neigh! Thump! Hiss! Cluck! Ribbit! Buzz! Haw hee haw! Pawoooo! Growls-grrr-grrr! Roars!

It is necessary to check how students have remembered the proposed associative symbols. The great advantage of using such exercises is the fact that children are not tired at all. Students perform movements and name them simultaneously. Everything is clear to them, because the language and the movements are intertwined. The main goal in this case is the orientation towards health-saving technologies in educational activity, etc.

Summary. The non-verbal associative component plays a significant part in teaching foreign languages to primary schoolchildren and helps to develop the personal qualities of students, their intellectual and cognitive abilities, and emotional readiness for communication. Associative exercises have a game purposefulness. Such activity helps to develop the concentration skills, independent thinking, attention, and discipline of children. The gaming aspects of exercises make the study interesting, create a cheerful mood for students, and facilitate overcoming linguistic difficulties in mastering a foreign language material. Associative exercises make it possible to change a complex educational material into a simple one, and a boring material into an interesting one.

In further papers it is planned to work out and offer linguistic exercises for the development of foreign language skills in speaking using the Wimmelbuch for the New Ukrainian School.

\section{СПИСОК ВИКОРИСТАНИХ ДЖЕРЕЛ}

$\begin{array}{lllll}1 . & \text { Невербальні засоби спілкування. } & \text { (б.д.). Взято }\end{array}$ http://pidruchniki.com/1081080640619/dokumentoznavstvo/neverbalni_zasobi_spilkuvannya

$\begin{array}{lllll}\text { 2. Структура невербальної } & \text { комунікації. } & \text { (б.д.). }\end{array}$ http://stud.com.ua/67644/marketing/struktura_neverbalnoyi_komunikatsiyi

3. Що змінює для дітей новий закон «Про освіту»? / Українська правда. Життя. (б.д.). Взято 3 https://life.pravda.com.ua/society/2017/09/28/226693/

4. Lobachova, I. (2016). Specifics of Implementing Technology of Associative Teaching English at Primary School. Професіоналізм педагога: теоретичні й методичні аспекти, 4, 286-294 . Взято 3 http://pptma.dn.ua/index.php/uk/arkhiv-vipuskiv/za-2016-rik/336

5. Lobachova, I. (2017). Pedagogical Conditions of Using a Wimmelbuch at English Lessons at Primary School. Професіоналізм педагога: теоретичні й методичні аспекти, 5 (2), 246-255. Взято з http://pptma.dn.ua/files/2017/5-2/24.\%20Lobachova\%20s.\%20246-255.pdf 
The Methodological Aspect of Using Associated Exercises for Working with Wimmelbuch at English Lessons in Primary School

\title{
МЕТОДИЧНИЙ АСПЕКТ ВИКОРИСТАННЯ АСОЦІАТИВНИХ ВПРАВ ДЛЯ РОБОТИ З ВІММЕЛЬБУХАМИ НА УРОКАХ АНГЛІЙСЬКОЇ МОВИ В ПОЧАТКОВІЙ ШКОЛІ
}

\author{
Ірина Лобачова \\ кандидат філологічних наук, \\ доцент кафедри теорії і практики початкової освіти \\ ДВНЗ «Донбаський державний педагогічний університет» \\ м. Слов'янськ Донецької області, Україна \\ http://orcid.org/0000-0001-7102-1915 \\ sbitneva.irina@ukr.net
}

\begin{abstract}
Анотація. У статті розкрито методичний аспект використання асоціативних вправ для роботи 3 ілюстративним матеріалом книжок-розглядинок (виммельбухами) на уроках англійської мови в початковій школі. 3'ясовано, що особливого значення набуває навчання іноземної мови молодших школярів $6-7$ років, вікові особливості яких обумовлюють рухову та моторну активність і значну роль невербального компонента в самовираженні. Визначено, що невербальні дії займають важливе місце в спілкуванні та здійснюють значний вплив на співрозмовника, тому це слід ураховувати при навчанні іншомовної комунікації. Авторкою доведено, що ілюстративний матеріал віммельбухів допомагає реалізувати засади концепції розвитку особистості в міжкультурній діяльності, що відповідає вимогам, які висуває сучасне суспільство до рівня та якості іншомовної освіти. Завдяки використанню асоціативних вправ під час роботи з віммельбухами на уроках англійської мови створюються умови як для розвитку здібностей молодших школярів, так і для підготовки їх до реального спілкування в рамках міжкультурних контактів, у яких необхідно розуміти і використовувати не лише вербальні, але й невербальні засоби спілкування.
\end{abstract}

Ключові слюва: асоціативні вправи; віммельбух; міжкультурна комунікація; невербальний компонент; учень початкової школи.

\section{МЕТОДИЧЕСКИЙ АСПЕКТ ИСПОЛЬЗОВАНИЯ АССОЦИАТИВНЫХ УПРАЖНЕНИЙ ДЛЯ РАБОТЫ С ВИММЕЛЬБУХАМИ НА УРОКАХ АНГЛИЙСКОГО ЯЗЫКА В НАЧАЛЬНОЙ ШКОЛЕ}

\author{
Ирина Лобачёва \\ кандидат филологических наук, \\ доцент кафедры теории и практики начального образования \\ ГВУЗ «Донбасский государственный педагогический университет» \\ г. Славянск Донецкой область, Украина \\ http://orcid.org/0000-0001-7102-1915 \\ sbitneva.irina@ukr.net
}

Аннотация. В статье раскрыто методический аспект использования ассоциативных упражнений для работы с иллюстративным материалом книг-гляделок (виммельбухами) на уроках английского языка в начальной школе. Выяснено, что особое значение приобретает обучение иностранному языку младших школьников $6-7$ лет, возрастные особенности которых определяют двигательную и моторную активность, и значительную роль невербального компонента в самовыражении. Определено, что невербальные действия

Професіоналізм педагога: теоретичні й методичні аспекти. - Вип. 7. - Слов’янськ, 2018. 
The Methodological Aspect of Using Associated Exercises for Working with Wimmelbuch at English Lessons in Primary School

занимают важное место в общении и осуществляют значительное влияние на собеседника, поэтому это следует учитывать при обучении иноязычной коммуникации. Автором доказано, что иллюстративный материал виммельбухов помогает реализовать принципы концепции развития личности в межкультурной деятельности, соответствующей требованиям, которые выдвигает современное общество к уровню и качеству иноязычного образования. Благодаря использованию ассоциативных упражнений при работе с виммельбухами на уроках английского языка создаются условия как для развития способностей младших школьников, так и для подготовки их к реальному общению в рамках межкультурных контактов, в которых необходимо понимать и использовать не только вербальные, но и невербальные средства общения.

Ключевые слова: ассоциативные упражнения; виммельбух; межкультурная коммуникация; невербальный компонент; ученик начальной школы.

\section{REFERENCES (TRANSLATED AND TRANSLITERATED)}

1. Non-verbal means of communication. (n.d.). Retrieved from http://pidruchniki.com/1081080640619/dokumentoznavstvo/neverbalni_zasobi_spilkuvannya

2. The structure of non-verbal communication. (n.d.). Retrieved from http://stud.com.ua/67644/marketing/struktura_neverbalnoyi_komunikatsiyi

3. What does the new law "On Education" change for children? / Ukrainian Truth. Life. (n.d.). Retrieved from https://life.pravda.com.ua/society/2017/09/28/226693/

4. Lobachova, I. (2016). Specifics of Implementing Technology of Associative Teaching English at Primary School. Profesionalizm pedahoha: teoretychni y metodychni aspekty, 4, 286-294. Retrieved from http://pptma.dn.ua/index.php/uk/arkhiv-vipuskiv/za-2016-rik/336

5. Lobachova, I. (2017). Pedagogical Conditions of Using a Wimmelbuch at English Lessons at Primary School. Profesionalizm pedahoha: teoretychni y metodychni aspekty, 5 (2), 246-255. Retrieved from http://pptma.dn.ua/files/2017/5-2/24.\%20Lobachova\%20s.\%20246-255.pdf

Матеріали надійшли до редакції 14.04.2018 р. 